\title{
GRM7 Gene
}

National Cancer Institute

\section{Source}

National Cancer Institute. GRM7 Gene. NCI Thesaurus. Code C114535.

This gene is involved in neurotransmitter binding. 